\title{
Utilization of Three Non-Edible Vegetable Oils for the Production of Biodiesel Catalysed by Enzyme
}

\author{
Sandip Kumar Haldar and Ahindra Nag* \\ Department of Chemistry, Indian Institute of Technology, Kharagpur, India
}

\begin{abstract}
Enzymatic transesterification by using lipase as catalyst has become more attractive for the production of biodiesel due to easy separation of products such as glycerol and fatty acid esters. Comparative studies of enzyme catalyzed transesterification of three less attended non edible oils (jatropha, karanja and putranjiva) have been discussed. The maximum yield has been obtained at 3:1 molar ratio of methanol and oil at $40^{\circ} \mathrm{C}$ and $8 \mathrm{hrs}$ reaction time. The percentage of conversion has been analyzed by Gas chromatography and $400 \mathrm{MHz}{ }^{1} \mathrm{H}$ NMR. It has been observed that degummed vegetable oil gives higher conversion in transesterification reaction than straight vegetable oil. Secondary alcohol gives better result than methanol for the production of biodiesel due to its higher miscibility nature in oil.
\end{abstract}

Keywords: Enzyme, oils, alcohol, transesterification, degumming.

\section{INTRODUCTION}

Biodiesel is defined as fatty acid methyl esters produced from vegetable oils or animal fats to be used as alternative diesel fuel. Biodiesel, a renewable fuel [1,2] made by transesterification of vegetable oil with alcohol, is becoming more readily available for blending with conventional diesel fuel for use in transportation applications. Soybean and Rapeseed oils are common feed stocks for biodiesel production in USA and Europe, respectively. Demand of biodiesel has increased significantly for higher escalation of petroleum price. In developing countries, the price paid for petrol, diesel and petroleum products now dominates over all other expenditures and forms a major part of country's import bill. Biodiesel is one of the renewable energy sources that can readily replace fossil fuels, while helping to reduce greenhouse gas emissions, promoting sustainable rural development, improvement of income distribution. Furthermore, the resulting substitution of current energy imports, mainly gasoline and diesel, is important for economic and national security reasons.

Production of biodiesel can be done by non-enzymatic (acid or alkali) and enzymatic processes. Enzymatic transesterification of triglycerides by lipase (3.1.1.3) is a good alternative process over the chemical process due to its ecofriendly, selective nature, low temperature requirement and easy product separation. Lipase breaks down the triacylglycerol into free fatty acids and glycerol that exhibit maximum activity at the oil-water interface. Under low water conditions, the hydrolysis reaction is reversible, i.e. the ester bond is synthesized rather than hydrolyzed.

Nag reported [3] efficiently catalyzed transesterification of various triglycerides and soybean oil in dry ethanol using celite immobilized commercial Candida rugosa lipase and

*Address correspondence to this author at the Department of Chemistry, Indian Institute of Technology, Kharagpur, India; Tel: +91-3222-281900; Fax: +91-3222-255303; E-mail: ahinnag @ chem.iitkgp.ernet.in its isoenzyme (lipase 4). Similarly Kaieda et al. [4] produced biodiesel from soybean oil and methanol using Rhizopus oryzae lipase as catalyst. Oda et al. [5] reported the methanolysis of the same oil using immobilized (on porous biomass support particles) Rhizopus oryzae lipase. Noureddini et al. [6] treated vegetable oil with methanol in presence of immobilized (on celite) enzyme Pseudomonas cepacia and yielded $67 \%$ biodiesel. The enzymatic transesterification of cottonseed oil was studied by Royon et al. [7] using immobilized Candida antarctica lipase as catalyst in t-butanol solvent. Du et al. [8] reported the production of biodiesel from soybean oil and methyl acetate in presence of lipase (Novozym 435). Kumar et al. [9] discussed the importance of non-edible oil Jatropha curcus as biodiesel production. Shah et al. [10] produced biodiesel from jatropha by enzyme in a solvent free system.

Gummy materials that present in vegetable oils inhibit the rate of enzymatic reaction. Viscosity plays another important factor for the production of biodiesel. In the present paper we have compared the production of biodiesel from three straight and degummed non-edible vegetable oils (jatropha, karanja and putranjiva) by enzymatic transesterification. We have also compared the viscosity of above mentioned three degummed oils with the straight vegetable oils. Karanja and putranjiva seeds give higher percentage of vegetable oils $(33 \% \mathrm{~m} / \mathrm{m}$ of dry kernels) but they are still unexplored for the use as biodiesel like jatropha.

\section{MATERIALS AND METHODS}

\section{Materials}

Jatropha, karanja and putranjiva seeds have been collected from Arabari forest (Midnapur, West Bengal, India) and the oils are obtained from seed kernel by mechanical pressing. Candida antartica lipase is purchased from SigmaAldrich Chemical Co, St. Louis, USA. Methanol, propane 2ol and hexane of analytical grade are used without being furthermore purification (E. Merck, Mumbai, India). 
Table 1. Fuel Properties of Three Non-Edible Oils and Diesel

\begin{tabular}{|c|c|c|c|c|}
\hline Kinematic Viscosity in cSt (at $\left.40^{\circ} \mathrm{C}\right)$ & 43.67 & 35.38 & 37.62 & 5.032 \\
\hline Calorific Value (kJ / kg) & 36258 & 38833 & 39582 & 42707 \\
\hline Flash Point $\left({ }^{\circ} \mathrm{C}\right)$ & 215 & 280 & 48 & 78 \\
\hline Fire Point $\left({ }^{\circ} \mathrm{C}\right)$ & 235 & 291 & 53 & 85 \\
\hline Carbon residue $(\%)$ & 1.4 & 0.2 & 0.9 & 0.1 \\
\hline
\end{tabular}

\section{Methods}

\section{a) Fuel Properties Measurement}

The physical and chemical properties of pure Karanja, Jatropha \& Putranjiva oils and their fatty acid methyl esters are measured and tabulated in Table $\mathbf{1}$. The calorific value is measured by Bomb Calorimeter (Petroleum Instruments India Pvt. Ltd.) according to ASTM D-4809. The kinematic viscosity is measured by Redwood Viscometer (Petroleum Instruments India Pvt. Ltd.). The flash point and fire point are determined by Pensky-Martens apparatus closed-cup method (ASTM D-93). The pour point is measured according to ASTM D-97. Carbon residue is measured by Conradson Method (ASTM D-189). The cetane number is determined by measuring the Aniline point. Diesel index is calcu- lated and cetane number is found by the formulation stated bellow.

Aaniline point index $(\mathrm{API})=\left(141.5 /\right.$ specific mass at $\left.15^{\circ} \mathrm{C}\right)-$ 131.5

Diesel Index $=\left(\right.$ Aniline point in ${ }^{0} \mathrm{~F} x$ API $) / 100$

Cetane Number $=0.72 \times$ Diesel Index +10

\section{b) Analysis of Fatty Acid Composition by Gas Chromatog- raphy (GC)}

The fatty acid compositions of three non-edible vegetable oils have been analyzed by a CN10543004 Gas Chromatography with a flame-ionization detector. The used capillary has a length of $30 \mathrm{~m}$ with an internal diameter of $0.25 \mathrm{~mm}$. Carrier gas is nitrogen at a flow rate of $1 \mathrm{ml} / \mathrm{min}$. The injec-

Table 2. The Percentage of Fatty Acid Compositions of Three Non-Edible Oils

\begin{tabular}{|c|c|c|c|}
\hline Composition (\%) & Putranjiva & Jatropha & Karanja \\
\hline C $14: 0$ & 0.03 & 0.07 & 0.04 \\
\hline C $16: 1$ & 0.07 & 1.03 & 0.06 \\
\hline C 17:0 & 0.07 & 0.11 & 0.10 \\
\hline C 18:0 & 10.63 & 6.31 & 9.27 \\
\hline C $18: 1$ & 48.65 & 39.15 & 52.65 \\
\hline C $18: 2$ & 27.50 & 35.80 & 18.19 \\
\hline C 22:0 & 0.24 & 0.09 & 2.70 \\
\hline C $22: 1$ & 0.03 & 0.05 & 0.03 \\
\hline C 24:0 & 0.31 & 0.05 & 0.85 \\
\hline
\end{tabular}

C 18:0 indicating the numbers of carbon in fatty acid are 18 and 0 unsaturation.

C 18:1 indicating the numbers of carbon in fatty acid are 18 and 1 unsaturation. 


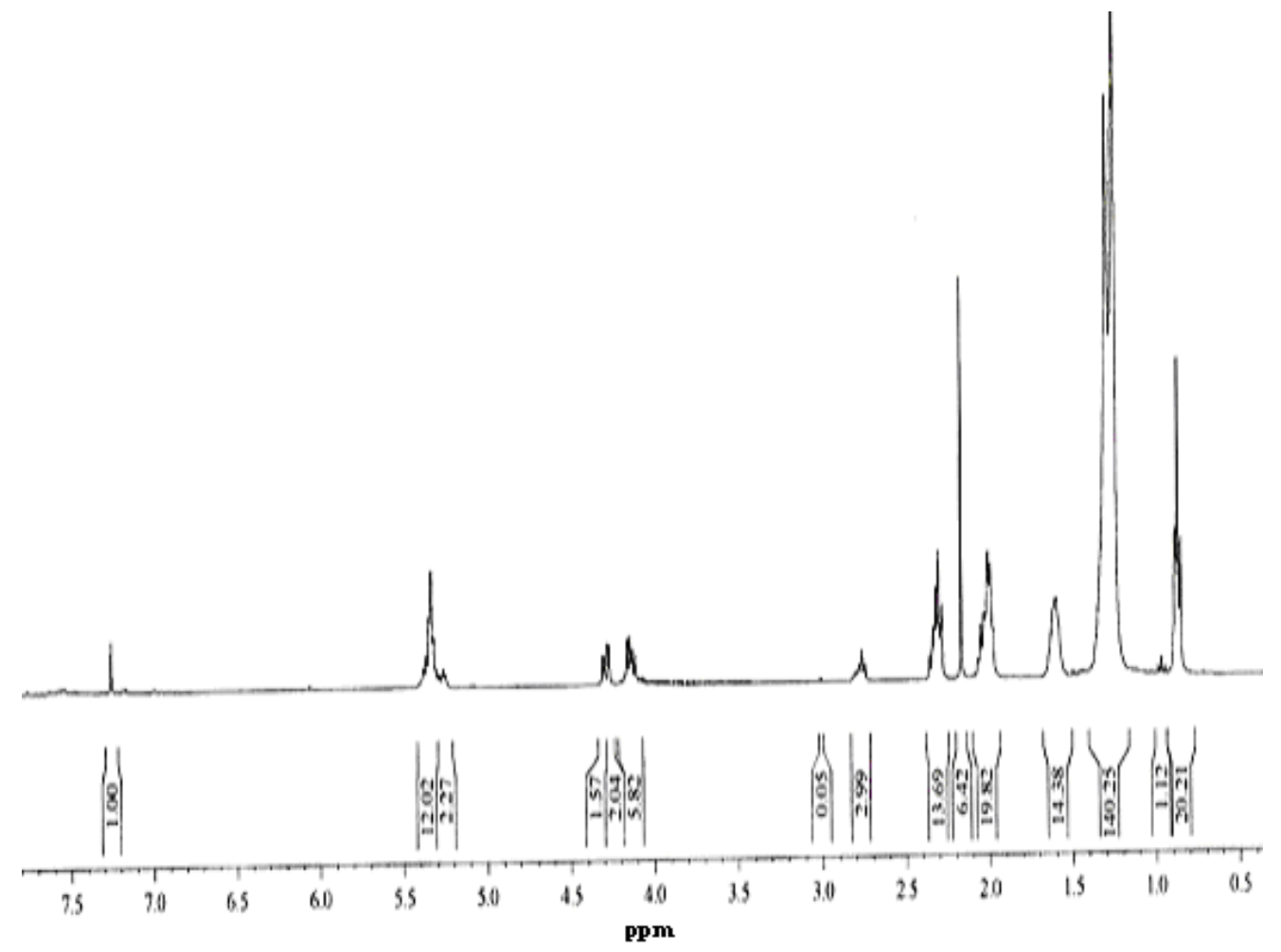

Fig. (1). NMR Spectra of unmodified Jatropha oil.

tion port temperature is $150^{\circ} \mathrm{C}$ and ionization detector temperature is $170^{\circ} \mathrm{C}$. The result of fatty acid compositions of three oils have shown in Table 2 . On comparative studies of three oils we have found that the domination of methyl esterified compounds are methyl oleate, methyl stearate, methyl linolate and methyl palmitate.

\section{c) Enzyme Catalyzed Transesterification}

Methanol and non-edible vegetable oil have been taken in a screw-capped conical flask. To this mixture, $10 \mathrm{ml}$ of hexane and $100 \mathrm{mg}$ of enzyme (Candida antartica lipase) as a catalyst have been added and incubated with constant shaking at $250 \mathrm{rpm}$. The reaction condition has been optimized by carrying out different sets of experiments with varying of alcohol to oil molar ratio, temperature and reaction time. The product formation has been monitored by thin layer chromatography (TLC). At the end of reaction, the content has been shaken with hexane $(30 \mathrm{ml})$ and the enzyme is separated by filtration. The reaction mixture is washed with distilled water to remove the glycerol and excess methanol. The ester phase is then dried by using anhydrous sodium sulphate. Hexane is removed by keeping the dried sample in the open air for three to four days. The quantification of ester has been done by $400 \mathrm{MHz}{ }^{1} \mathrm{H}-\mathrm{NMR}$ spectra.

\section{RESULTS AND DISCUSSION}

The molar ratio of methanol to vegetable oil is one of the most important variables that affecting the yields of methyl ester formation. The stoichiometry of the transesterification reaction is that three molecules of methanol react with one molecule of vegetable oil. The effect of molar ratio of methanol to vegetable oil has been studied in the range from $1: 1$ to 5:1 at temperature $40^{\circ} \mathrm{C}$ and $8 \mathrm{hrs}$ respectively. The resulting methyl esterified product has been analyzed by $400 \mathrm{MHz}{ }^{1} \mathrm{H}-$
$\mathrm{MHz}{ }^{1} \mathrm{H}-\mathrm{NMR}$ spectra. The percentage conversion has been calculated from the NMR spectra (Fig. (1), (2)) by considering the peak at $\delta=3.6$ (due to $-\mathrm{CH}_{3}$ ester proton) and $\delta=2.3$ (due to $\alpha$ methylene proton). The percentage conversion is equal to $\left(2 * \mathrm{~A}_{\delta=3.7} / 3 * \mathrm{~A}_{\delta=2.3}\right) * 100$, where $(\mathrm{A})$ is the integrated peak area at different chemical shift.

To determine the optimum temperature for conversion of methyl ester, the reaction has been carried out at different temperatures with a fixed molar ratio of methanol and oil (3:1). The maximum conversion has been achieved at $40^{\circ} \mathrm{C}$ which is considered as optimum temperature for product formation. The effect of reaction time has been determined by carrying out the reaction at different time with a fixed molar ratio of methanol and oil (3:1) and constant temperature $\left(40^{\circ} \mathrm{C}\right)$. The ester yield increased with increase in time and the maximum yield gives at 8 hours reaction time. The percentage of conversion to product of jatropha, karanja and putranjiva oils are shown in Table $\mathbf{3}$.

We have degummed the oils by treating with different percentage of sulphuric acid for 2 hrs. The treated oil has been purified by charred saw dust. Degumming by acid treatment lowers the viscosity of straight vegetable oils. The kinematic viscosities of degummed vegetable oils in various acids concentration at $40^{\circ} \mathrm{C}$ are shown in Fig. (3). Karanja oil of $4 \% \mathrm{~m} / \mathrm{m}$ acid treating shows the lowest viscosity where as jatropha and putranjiva both shows the lowest viscosity at $1 \% \mathrm{~m} / \mathrm{m}$ acid treatment.

Transesterification are also carried out of degummed oils by methanol. It has been observed that percentage conversion of degummed oils to the product is increased by $14 \%$, $12 \%$ and $8 \%$ in case of jatropha, karanja and putranjiva (Table 3). Hence phospholipids, carotene, protein etc gummy materials present in straight vegetable oil may inhibit the 


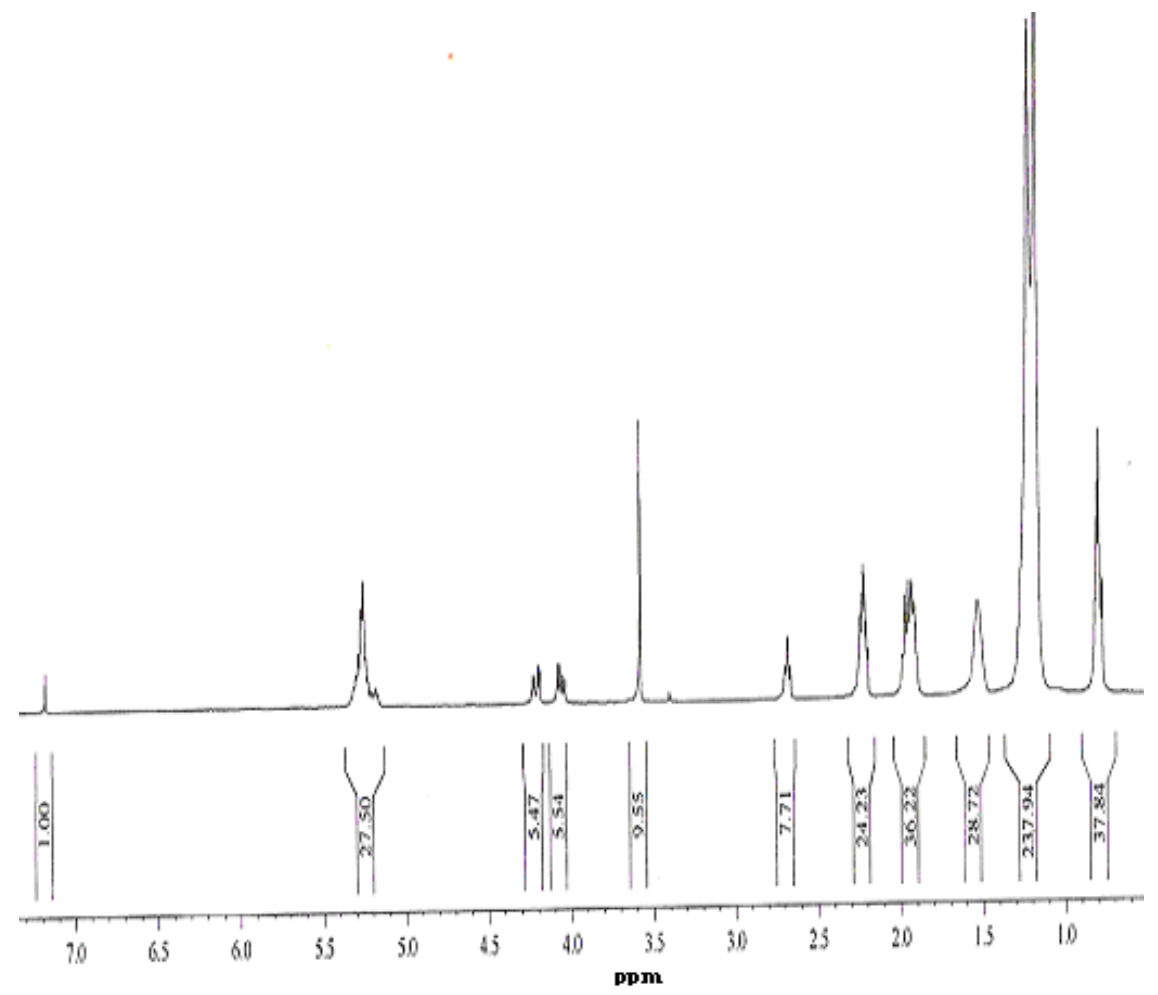

Fig. (2). NMR Spectra of transesterified Jatropha oil with methanol.

Table 3. Transesterification of Three Non -Edible Oils

\begin{tabular}{|c|c|c|}
\hline Oil & \% Conversion without Degumming & \% Conversion after Degumming \\
\hline \hline Jatropa & 52 & 66.6 \\
\hline Koranja & 27 & 39 \\
\hline Putranjiva & 17.7 & 25 \\
\hline
\end{tabular}

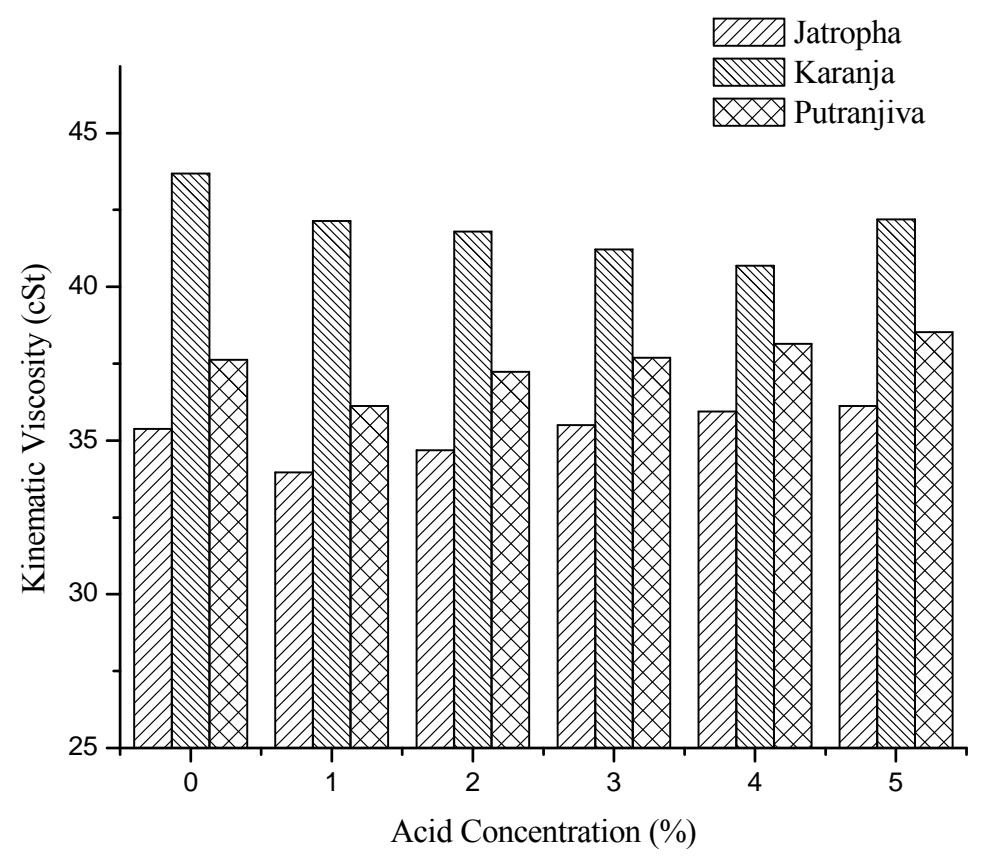

Fig. (3). Kinematic Viscosity vs. acid concentration of Jatropha, Karanja and Putranjiva oil at $40^{\circ} \mathrm{C}$. 
alcoholysis reaction. This is due to interaction of the lipase molecule with gummy substrates. Usually some short chain alcohols like methanol have been adopted as the acyl acceptor for biodiesel production. However, excess methanol would lead to the inactivation of enzyme. Glycerol, as a major byproduct, lowers also the enzymatic activity. The lipase becomes inactivated seriously in the presence of one equivalent mole of methanol in the reaction medium. The reason for the low conversion of methyl ester is the poor miscibility of triacylglycerol (TAG) with methanol which exists as droplets in the oil and being polar in nature gets adsorbed by the lipase, thereby blocks the entry of triacylglycerols, causing the reaction to stop.

The activity of lipase that is deactivated by methanol [3] can be restored to a certain extent by treating the enzyme with secondary alcohol such as propan-2-ol. It has been observed that propan-2-ol used as an acyl acceptor so as to bring the enzymatic approach to biodiesel production from straight vegetable oils of jatropha and karanja. The conversions are achieved by using propan-2-ol are $72 \%$ and $45 \%$ $\mathrm{m} / \mathrm{m}$ from straight jatropha and karanja oils respectively. The appearance of the signal at $(5.0 \mathrm{ppm}$, septet) and the disappearance of the hydrogen signals of the TAG backbone (4.1$4.3 \mathrm{ppm}$, multiplet) confirms the formation of 2-propyl esters. On comparison of propan-2-ol and methanol, propan-2ol displays better miscibility in oil and is less polar (polarity index being 3.9 and 5.1 for propan-2-ol and methanol respectively) than methanol. Thus propan-2-ol is a promising acyl acceptor for the production of biodiesel by lipase catalyst as it has no negative effect on the lipase activity.

\section{ACKNOWLEDGEMENT}

The authors gratefully acknowledge the financial support of the Department of Science and Technology (DST), India.

\section{REFERENCES}

[1] S. Kumar, A.K. Gupta, S.N. Naik, "Conversion of non-edible oil into biodiesel", Journal of Scientific and Industrial Research, vol. 62 (1), pp. 124-132, 2003.

[2] R. Sarin, M. Sharma, S. Sinharay, R.K. Malhotra, "Jatropha-Palm biodiesel blends: An optimum mix for Asia”, Fuel, vol. 86 (10-11), pp. 1365-1371, 2007.

[3] A. Nag, "Alcoholysis of vegetable oil catalyzed by an isoenzyme of Candida rugosa lipase for production of fatty acid esters", Ind. J. Biotechnology, vol. 5, pp.175-178, 2006.

[4] M. Kaieda, T. Samukawa, T. Matsumoto, K. Ban, A. Kondoa, "Biodiesel Fuel Production from Plant Oil Catalyzed by Rhizopus oryzae lipase in a Water-Containing System without an organic solvent", Journal of Bioscience Bioengineering, vol. 88, pp. 627631, 1999.

[5] M. Oda, M. Kaieda, S. Hamab, H. Yamajia, A. Kondoa, E. Izumotoc, H. Fukuda, "Facilitatory effect of immobilized lipaseproducing Rhizopus oryzae cells on acyl migration in biodiesel-fuel production”, Biochemical Engineering Journal, vol. 23, pp. 45-51, 2005.

[6] H. Noureddini, X. Gao, R.S. Philkana, "Immobilized Pseudomonas cepacia lipase for biodiesel fuel production from soybean oil", Bioresource Technology, vol. 96, pp. 769-777, 2005.

[7] D. Royon, M. Daza, G. Ellenriedera, S. Locatellia, "Enzymatic production of biodiesel from cotton seed oil using t-butanol as a solvent", Bioresource Technology, vol. 98, pp. 648-653, 2007.

[8] W. Du, Y. Xu, D. Liu, J. Zeng, "Comparative study on lipasecatalyzed transformation of soybean oil for biodiesel production with different acyl acceptors", Journal of Molecular Catalysis B Enzymatic, vol. 30, pp. 125-129, 2004.

[9] N. Kumar, P.B. Sharma, "Jatropha curcus - A sustainable source for production of biodiesel", Journal of Scientific and Industrial Research, vol. 64(11), pp. 883-889, 2005.

[10] S. Shah, M.N. Gupta, "Lipase catalyzed preparation of biodiesel from Jatropha oil in a solvent free system", Process Biochemistry, vol. 42(3), pp.409-414, 2007. 